\title{
Serum periostin levels in adults of Chinese descent: an observational study
}

\author{
Evan Tan ${ }^{1}$, Rachel Varughese ${ }^{1}$, Ruth Semprini ${ }^{1,2^{*}} \mathbb{0}$, Barney Montgomery ${ }^{6}$, Cecile Holweg ${ }^{3}$, Julie Olsson ${ }^{3}$, \\ Rachel Caswell-Smith1', James Fingleton ${ }^{1,5}$, Mark Weatherall ${ }^{1,4}$, Richard Beasley ${ }^{1,2,5}$ and Irene Braithwaite ${ }^{1,2,5}$
}

\begin{abstract}
Background: Periostin has been shown to be a marker of Type 2 airway inflammation, associated with airway eosinophilia. It has a potential role in identifying asthmatics who may be responsive to treatment with monoclonal antibody therapy directed against Type 2 cytokines, such as interleukin (IL)-13, IL-4 receptor subunit-a and immunoglobulin $\mathrm{E}$. The clinical utility of periostin measurements depends on better understanding of factors that may affect serum periostin levels, such as race. We aimed to identify the ranges of serum periostin in Chinese adults both with and without asthma, and compare them with those previously identified in Caucasian adults.
\end{abstract}

Methods: A two-centred cross-sectional study, recruiting 188 Chinese adults, aged 18 to 75 years. 120 participants had no history of asthma or chronic obstructive pulmonary disease. 68 participants had a doctor's diagnosis of asthma and were on current treatment. Univariate comparisons of periostin by dichotomous variables were made using t-tests with logarithmic transformation as the distribution of periostin was skewed.

Results: In the Chinese non-asthma group, periostin levels were sex-, but not age-dependent, with females having higher periostin levels. The individual predicted $(90 \% \mathrm{Cl})$ reference range for periostin in females was $61.1 \mathrm{ng} / \mathrm{ml}(41.6$ to 89.8$) \mathrm{ng} / \mathrm{ml}$ and in males was $53.2 \mathrm{ng} / \mathrm{ml}(36.1$ to 78.3$) \mathrm{ng} / \mathrm{ml}$. There was no difference in median serum periostin levels between Chinese non-asthmatics and Chinese asthmatics, 57.0 versus $56.8 \mathrm{ng} / \mathrm{ml}$, difference (95\% Cl) 0.1 ( -4.2 to 4.2$) \mathrm{ng} / \mathrm{ml}, \mathrm{P}=0.94$. The median serum periostin levels were higher in Chinese non-asthmatics than Caucasian nonasthmatics, 57.0 versus $49.7 \mathrm{ng} / \mathrm{ml}$, difference $(95 \% \mathrm{Cl}) 8.2(5.8-10.6) \mathrm{ng} / \mathrm{ml}, \mathrm{P}<0.001$.

Conclusions: Serum periostin does not discriminate between asthmatics and non-asthmatics and is therefore not a good biomarker to diagnose asthma. Serum periostin levels were higher in the Chinese compared to the Caucasian non-asthma group, and also sex dependent in the Chinese participants. There was no difference in serum periostin levels between Chinese non-asthma and asthma groups. This suggests that ethnicity should be considered in the interpretation of periostin levels in asthma patients and sex is an additional consideration in Chinese patients.

Trial registration This trial was prospectively registered with Australian New Zealand Clinical Trials Registry (ACTRN12614000122651)

Keywords: Adult, Asthma, Biomarkers, Chinese, Periostin

\footnotetext{
*Correspondence: ruth.semprini@ccdhb.org.nz

${ }^{1}$ Medical Research Institute of New Zealand, Private Bag 7902, Newtown,

Wellington 6242, New Zealand

Full list of author information is available at the end of the article
} 


\section{Background}

Periostin, a matricellular protein, has been shown to be a marker of Type 2 inflammation associated with airway eosinophilia $[1,2]$. It has a potential role in identifying asthmatics who may be responsive to treatment with monoclonal antibody therapy directed against Type 2 cytokines, such as interleukin (IL)13 [3, 4], IL-4 receptor subunit- $\alpha$ (IL-4R $\alpha)$ [5] and immunoglobulin E (IgE) [6], and may have a role in helping define asthma sub-phenotypes when used in conjunction with other Type 2 biomarkers [7]. The clinical utility of periostin measurements depends on better understanding of factors that may affect serum periostin levels, such as race.

We have recently reported reference ranges for serum periostin both in an adult group without asthma [8] and in an adult group with symptomatic airflow obstruction [9]. In both these studies, participants who identified as being 'Asian' had a trend towards higher serum periostin levels than their Caucasian counterparts. However, the interpretation of these findings was difficult, as in both studies the proportion of people from an Asian background was small, comprising 34/480 (7\%) and 9/386 (2\%) of the clinical cohorts, respectively, and the origin of the Asian participants was not further defined.

In this study, we aimed to identify the range for serum periostin in adult Chinese participants both with and without asthma, and compare the ranges with those previously described in Caucasian populations $[8,9]$. The methodology was based on the guidelines of the Clinical and Laboratory Standards Institute for determining reference values and reference intervals for quantitative clinical laboratory tests [10]. We also investigated whether periostin levels differed in Chinese with and without asthma and whether or not country of birth influenced serum periostin levels in the Chinese groups.

\section{Methods}

This was a two-centre, cross-sectional study which recruited Chinese adults, aged 18 to 75 years, from the Greater Wellington and Auckland regions. To be eligible for inclusion, participants were required to self-report both their own, as well as their parents', race as Chinese. The study consisted of 188 Chinese participants, divided into non-asthma and asthma groups. For each Chinese group there was a comparator Caucasian group comprising participants who self-reported their race as New Zealand European, derived from previous studies $[8,9]$.

\section{Participants}

Non-asthmatic Chinese group

120 Chinese participants, without a doctor's diagnosis of asthma or chronic obstructive pulmonary disease (COPD), with at least 20 participants (10 male and 10 female) recruited to each of the following age bands: $18-30,31-45,46-60$ and $61-75$ years.

\section{Non-asthmatic comparator Caucasian Group}

420 Caucasian adults, without a doctor's diagnosis of asthma or COPD, aged 18-75 years, were derived from a previous study identifying reference ranges of periostin in an adult non-asthmatic population [8].

For both non-asthmatic groups, participants were excluded if they were current smokers, or former smokers with a smoking history of greater than 10 pack years; underwent surgery (including dental surgery), were admitted to hospital, sustained a bone fracture or received systemic corticosteroids within 3 months of enrolment; were pregnant or breastfeeding; or had an active (within 3 weeks prior to the study visit) respiratory tract infection, as these scenarios could potentially influence serum periostin levels.

\section{Asthmatic Chinese group}

68 Chinese participants with a doctor's diagnosis of asthma whose current asthma treatment was either of: (i) short-acting beta agonist (SABA) only, or (ii) SABA and at least one controller. This group had the same other exclusion criteria as the non-asthmatic groups.

\section{Comparator asthmatic Caucasian Group}

170 Caucasian adults, with a doctor's diagnosis of asthma and aged between 18 and 75 years were derived from a previous study of an adult population with symptomatic airflow obstruction [9], and were stratified as above, based on their asthma treatment.

The study conformed to the standards of the Declaration of Helsinki. Ethical approval was given by the Central Regional Ethics Committee of New Zealand (13/NTB/190). Written informed consent was obtained from all participants prior to testing. Participants attended the nearest research facility for a single visit for assessment of medical history, completion of a genogram to document race and country of birth, measurement of spirometry and fractional exhaled nitric oxide (FeNO), and blood sampling for measurement of full blood count (FBC), creatinine and electrolytes, serum IgE and serum periostin. Asthmatic participants answered additional validated respiratory health questionnaires, Asthma Control Questionnaire (ACQ-5) [11] and Asthma Quality 
of Life Questionnaire with Standardised Activities (AQLQ-S) [12], to establish their current asthma control. Medication history for all participants was recorded.

\section{Spirometry and FeNO}

Spirometry was performed for measurement of forced expired volume in one second $\left(\mathrm{FEV}_{1}\right)$ and forced vital capacity (FVC) using a Masterscreen Pneumo (Masterscreen Version 2.0, Carefusion, Germany) in accordance with the American Thoracic Society (ATS) guidelines [13]. $\mathrm{FEV}_{1} \%$ predicted values were calculated using the Global Lung Initiative equations [14]. FeNO was assessed using a nitric oxide monitor (NiOX, Aerocrine AB, Sweden) according to ATS guidelines [15].

\section{Blood samples}

All participants, including from the previous cohorts, underwent venepuncture for measurement of serum periostin, which was determined using the Elecsys ${ }^{\circledR}$ Periostin immunoassay (Roche Diagnostics, Penzberg, Germany). The Elecsys ${ }^{\circledR}$ Periostin assay was developed according to the guidelines of the Clinical and Laboratory Institute (CLSI) and is a fully automated immunoassay operated on the e601 module of the cobas 6000 system equipped with software version 05-01 or higher [16]. The assay has a high repeatability with coefficients of variation across multiple sites and reagent lots of 1.7 to 3.1\% [16]. Blood samples were coagulated, centrifuged and serum aliquots stored at $-80{ }^{\circ} \mathrm{C}$ prior to analysis. FBC and white cell differential (Sysmex platform, Mundelein, USA), urea and electrolytes (Roche, Cobas 501, NZ) and serum IgE (Roche modular, Indianapolis, USA) were performed immediately in local laboratories.

\section{Study power}

The sample size of 120 non-asthmatic Chinese adults (60 male; 60 female) was based on the recommendations of the Clinical and Laboratory Standards Institute [10], to allow $90 \%$ confidence intervals to be computed by nonparametric methods if normal distribution assumptions were not met. Based on the standard deviation (SD) of logarithm periostin of 0.22 , a sample size of 120 Chinese participants and 420 Caucasian participants had 90\% power with alpha $5 \%$ to detect a difference in mean logarithm periostin of 0.074 which is equivalent to a ratio of mean periostin of 1.08 .

\section{Statistical methods}

Data descriptions for continuous variables were by mean, median, and minimum to maximum ranges. Serum IgE, FeNO and serum periostin had skewed distributions, so were analysed on the logarithm transformed scale. For univariate comparison of continuous variables by dichotomous variables, t-tests were used, using a logarithm transformation when needed. For completeness, for those variables analysed on the logarithm transformed scale, the univariate association by a Mann-Whitney test and HodgesLehmann estimator of location shift were also shown. Where a logarithm transformation of a response variable was carried out, the exponent of this was shown and was interpreted as the ratio of geometric means.

Estimates of the mean and median periostin levels and $90 \%$ confidence intervals for prediction were determined for the Chinese non-asthma group with an analysis of variance (ANOVA). The sex and age adjusted reference range for periostin was estimated by analysis of co-variance (ANCOVA). We performed the analysis on the logarithm transformed scale with a back transformation to establish the $90 \%$ confidence interval for prediction.

An estimate of the difference between the Chinese and Caucasian groups was calculated by a general linear model (ANOVA). An exploratory analysis, comprising a $t$ test, was done to examine the effects of country of birth on serum periostin levels. Finally, ANOVA and ANCOVA were used to examine the association between periostin (using logarithm periostin as the response variable) and the interaction between race and asthma status without (ANOVA) and with (ANCOVA) adjustment of the continuous co-variates body mass index (BMI) and $\mathrm{FEV}_{1} \%$ predicted.

SAS version 9.4 was used.

\section{Results}

The flow of Chinese participants through the study is shown in Fig. 1. Participants were recruited between May and November 2015 from both sites. A total of 182 people were screened, of which nine were excluded. 12 participants, who self-identified as Chinese from a previous study [8] were included in the Chinese nonasthma group, and were part of the final analysis. A total of 185 Chinese participants had complete data, which was analysed and is presented here.

\section{Participant characteristics}

Participant characteristics are described in Table 1 (non-asthmatic Chinese and Caucasians) and Table 2 (asthmatic Chinese and Caucasians).

Serum periostin reference range in non-asthmatic Chinese In the Chinese non-asthma group, periostin levels were sex-, but not age-dependent, with females having higher periostin levels, with a ratio of geometric mean periostin (95\% CI) 1.15 (1.05 to 1.26 ), $\mathrm{P}=0.001$. Using the mean age in this group (42.2 years), the back-transformed 


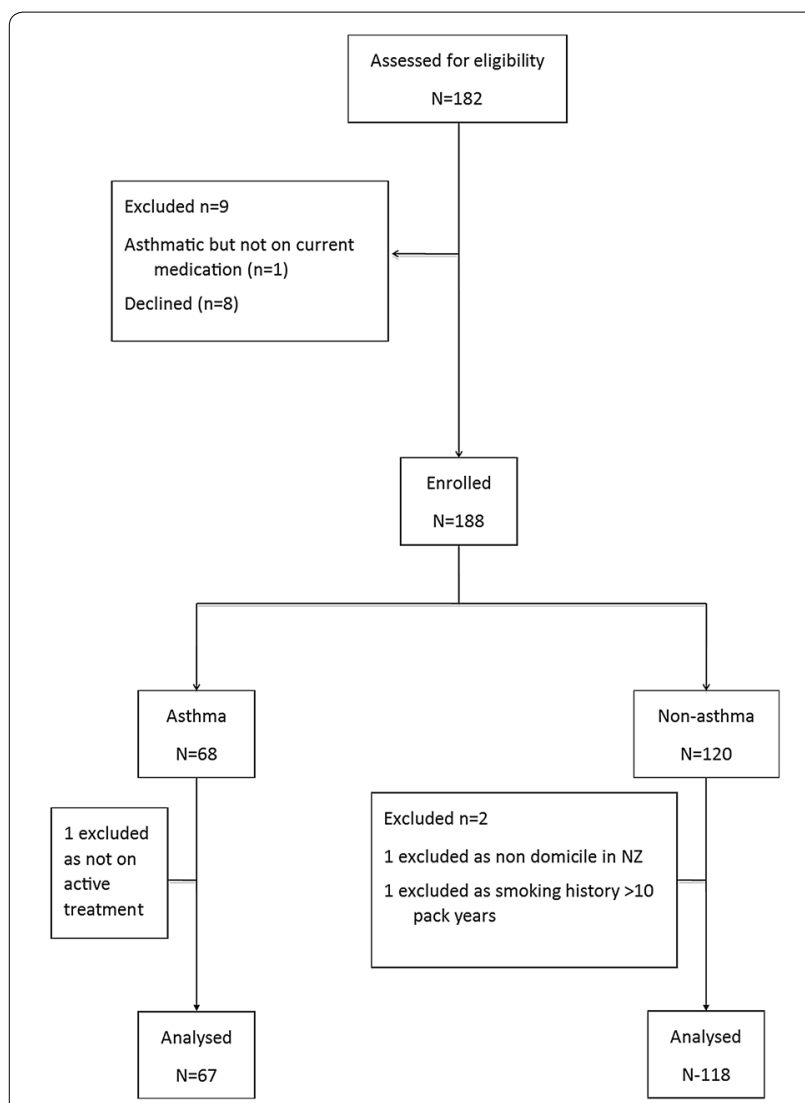

Fig. 1 Flow of Chinese participants through the study

individual predicted $(90 \% \mathrm{CI})$ reference range for periostin in females was $61.1 \mathrm{ng} / \mathrm{ml}(41.6$ to 89.8$) \mathrm{ng} / \mathrm{ml}$ and in males was $53.2 \mathrm{ng} / \mathrm{ml}$ (36.1 to 78.3$) \mathrm{ng} / \mathrm{ml}$. There was an inverse relationship between logarithm serum periostin and $\mathrm{BMI}(\mathrm{r}=-0.28, \mathrm{P}=0.002)$.

\section{Group comparisons}

\section{Non-asthmatic Chinese and non-asthmatic Caucasians}

The Chinese non-asthmatic group had more females $(77 / 118,68 \%$ of total) and a lower mean BMI than the Caucasian group. Atopic conditions, such as seasonal rhinoconjunctivitis or eczema, were less prevalent in the Chinese group, $32.2 \%$, compared to $48.3 \%$ in the Caucasian group. The median (interquartile range; IQR) serum periostin level was higher in Chinese nonasthmatics, 57.0 (50.3 to 67.9) $\mathrm{ng} / \mathrm{ml}$, than in Caucasian non-asthmatics, 49.7 (42.8 to 56.5$) \mathrm{ng} / \mathrm{ml}$. The HodgesLehmann estimate $(95 \% \mathrm{CI})$ of the difference was 8.2 (5.8 to 10.6$), \mathrm{P}<0.001$. Figure 2 shows comparative frequency histograms of logarithm transformed serum periostin in Chinese and Caucasian non-asthmatics. With respect to other biomarkers of Type 2 asthma, serum IgE was higher in the Chinese non-asthmatic group compared to the Caucasian group. There was no difference between the groups with respect to peripheral blood eosinophils or FeNO.

\section{Asthmatic Chinese and non-asthmatic Chinese}

The Chinese asthma group had a higher proportion of males, 37/67 (55\%), and were younger than the Chinese non-asthmatics (Tables 1 and 2). A history of atopic conditions, including nasal disorders, was more prevalent in Chinese asthmatics, 48/67 (71.6\%). There was no significant difference in serum periostin between the Chinese asthma and non-asthma groups, median $56.8 \mathrm{ng} / \mathrm{ml}$ and $57.0 \mathrm{ng} / \mathrm{ml}$ respectively, with a HodgesLehmann estimate of $(95 \% \mathrm{CI})-0.1$ ( -4.2 to 4.2$)$, $\mathrm{P}=0.94$. Peripheral blood eosinophils, $\mathrm{FeNO}$ and serum IgE, were higher in Chinese asthmatics.

\section{Asthmatic Chinese and asthmatic Caucasians}

The Chinese asthma group had a lower BMI than the Caucasian group and a higher mean $\mathrm{FEV}_{1} / \mathrm{FVC}$ ratio and higher $\mathrm{FEV}_{1} \%$ predicted values. Spirometric differences were consistent with a lower proportion of Chinese participants being on Global Initiative for Asthma (GINA) treatment Step 2 or higher; 33/67 (49\%) in the Chinese group and 106/170 (62\%) in the Caucasian group. Median serum periostin levels between the two groups were similar $(56.8 \mathrm{ng} / \mathrm{ml}$ in Chinese and $54.9 \mathrm{ng} /$ $\mathrm{ml}$ in Caucasians). There was evidence of modest interaction between race and asthma status on serum periostin levels with an unadjusted value $\mathrm{P}=0.01$, and a value of $\mathrm{P}=0.024$ after adjustment for $\mathrm{BMI}$ and $\mathrm{FEV}_{1} \%$ predicted. With respect to other biomarkers of Type 2 asthma, blood eosinophils were similar with means (SD) of $0.29(0.19) \times 10^{9} / \mathrm{L}$ and $0.27(0.22) \times 10^{9} / \mathrm{L}$ in Chinese and Caucasian asthmatics. However, FeNO and IgE were higher in Chinese asthmatics with a mean (SD) FeNO of 64.4 (54.8) $\mathrm{ppb}$ and IgE $537.6(632.9) \mathrm{IU} / \mathrm{ml}$ compared to 39.3 (33.2) $\mathrm{ppb}$ and 372.8 (1429) $\mathrm{IU} / \mathrm{ml}$ in Caucasian asthmatics.

\section{Country of birth and serum periostin levels in Chinese participants}

Of the 185 Chinese participants with periostin data, 93 participants were born in New Zealand and 92 participants were immigrants to New Zealand. All participants had lived in New Zealand for at least 1 year prior to enrolment into the study. As there was no difference in serum periostin between the Chinese asthma and non-asthma groups, this analysis was performed on all Chinese participants, irrespective of their asthma status. There was no difference in periostin levels between those who were born in New Zealand and 


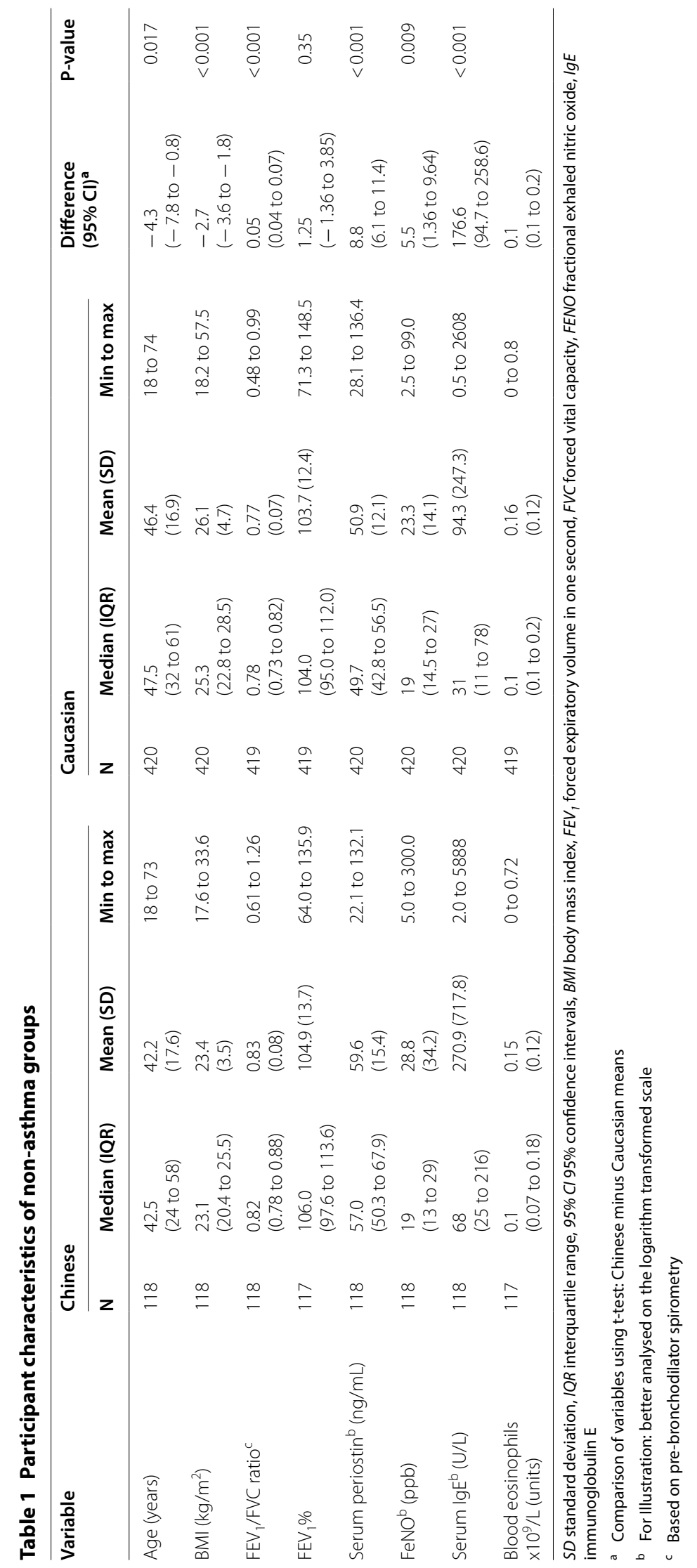


Table 2 Participant characteristics of asthma groups

\begin{tabular}{|c|c|c|c|c|c|c|c|c|}
\hline \multirow[t]{2}{*}{ Variable } & \multicolumn{4}{|c|}{ Chinese } & \multicolumn{4}{|c|}{ Caucasian } \\
\hline & $\mathbf{N}$ & Median (IQR) & Mean (SD) & Min to $\max$ & $\mathrm{N}$ & Median (IQR) & Mean (SD) & Min to $\max$ \\
\hline Age (years) & 67 & $\begin{array}{l}32 \\
\text { (22 to } 52 \text { ) }\end{array}$ & $37.3(16.3)$ & 18.4 to 72.4 & 170 & $\begin{array}{l}46 \\
\text { (35 to } 57 \text { ) }\end{array}$ & $46.0(14.5)$ & 19 to 75 \\
\hline BMI $\left(\mathrm{kg} / \mathrm{m}^{2}\right)$ & 67 & $\begin{array}{l}24.9 \\
\text { (22.2 to } 26.6)\end{array}$ & $24.9(3.9)$ & 17.6 to 37.4 & 170 & $\begin{array}{l}26.5 \\
\text { (22.7 to } 30.9 \text { ) }\end{array}$ & $27.7(6.7)$ & 15.7 to 57.1 \\
\hline $\mathrm{FEV}_{1} / \mathrm{FVC}$ ratio $^{\mathrm{a}}$ & 67 & $\begin{array}{l}0.76 \\
(0.70 \text { to } 0.81)\end{array}$ & $0.74(0.11)$ & 0.43 to 0.96 & 170 & $\begin{array}{l}0.74 \\
\text { (0.66 to } 0.79 \text { ) }\end{array}$ & $0.72(0.11)$ & 0.38 to 0.95 \\
\hline FEV $1 \%$ predicted & 67 & $\begin{array}{l}99.5 \\
\text { (83.3 to } 107.5)\end{array}$ & $95.3(16.6)$ & 50.1 to 130.5 & 170 & $\begin{array}{l}84.8 \\
\text { (74.4 to } 94.1 \text { ) }\end{array}$ & $83.1(16.3)$ & 32.6 to 121.8 \\
\hline Serum periostin ${ }^{\mathrm{b}}(\mathrm{ng} / \mathrm{mL})$ & 67 & $\begin{array}{l}56.8 \\
\text { (47.8 to } 70.4 \text { ) }\end{array}$ & $59.9(15.3)$ & 36.4 to 128.2 & 170 & $\begin{array}{l}54.9 \\
(47.3 \text { to } 68.0)\end{array}$ & $58.9(19.9)$ & 15.0 to 148 \\
\hline $\mathrm{FeNO}^{\mathrm{b}}(\mathrm{ppb})$ & 67 & $\begin{array}{l}41 \\
23 \text { to } 96)\end{array}$ & $64.4(54.8)$ & 7.0 to 242 & 170 & $\begin{array}{l}30.5 \\
\text { (16.5 to } 49.4)\end{array}$ & $39.3(33.2)$ & 2.7 to 194.1 \\
\hline Serum lg $E^{b}(U / L)$ & 66 & $\begin{array}{l}308 \\
\text { (128 to } 738)\end{array}$ & $537.6(632.9)$ & 7.0 to 3454 & 170 & $\begin{array}{l}125.4 \\
\text { (34 to 283.1) }\end{array}$ & $372.8(1429.0)$ & 1 to 18,083 \\
\hline Blood eosinophils $\times 10^{9} / \mathrm{L}$ (units) & 67 & $\begin{array}{l}0.24 \\
(0.14 \text { to } 0.40)\end{array}$ & $0.29(0.19)$ & 0.02 to 0.78 & 170 & $\begin{array}{l}0.2 \\
(0.1 \text { to } 0.3)\end{array}$ & $0.27(0.22)$ & 0 to 1.5 \\
\hline
\end{tabular}

SD standard deviation, IQR interquartile range, $95 \%$ CI 95\% confidence intervals, BMI body mass index, $F E V_{1}$ forced expiratory volume in one second, FVC forced vital capacity, FeNO fractional exhaled nitric oxide, IgE immunoglobulin $\mathrm{E}$

a Based on pre-bronchodilator measurements

b For Illustration: better analysed on the logarithm transformed scale
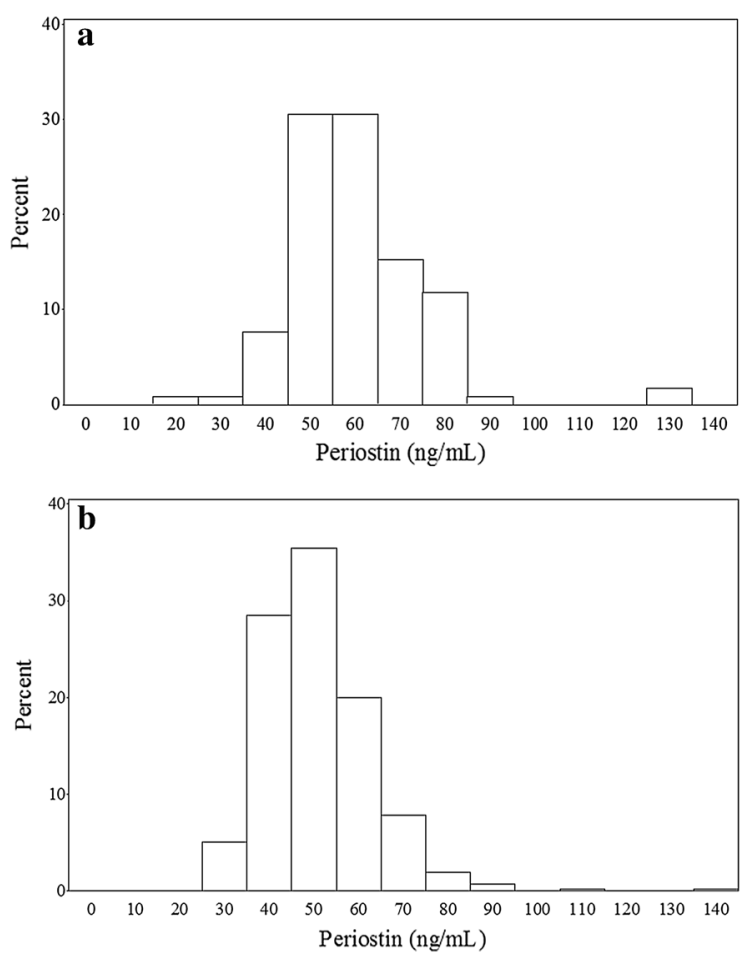

Fig. 2 Histograms illustrating the differences between distribution of serum periostin between Chinese $(n=118)$ and Caucasians $(n=420)$ without asthma. Median periostin levels were higher in Chinese non-asthmatics compared to Caucasian non-asthmatics. a Chinese frequency histogram. b Caucasian frequency histogram those born elsewhere, with a Hodges-Lehmann estimate (95\% CI) of -1.3 ( -5.1 to 2.6 ), $\mathrm{P}=0.51$, (Fig. 3).

\section{Discussion}

The main findings of this study were that serum periostin levels were higher in non-asthmatic Chinese compared to non-asthmatic Caucasians and there was no difference in periostin levels between Chinese adults with and without asthma.

Some of the associations we have found should be interpreted cautiously. As this was an exploratory study investigating a potential difference in serum periostin levels between Chinese and Caucasian populations, performing multiple statistical tests may have resulted in Type I error inflation. Secondly, we recruited people who self-reported their race as Chinese. To mitigate against issues around race identity, participants completed a genogram in which both of their parents were also required to identify as Chinese. Thirdly all participants were resident in New Zealand for at least a year prior to enrolment, in order to minimise potential confounding of environmental factors, such as indoor or outdoor air pollution, on serum periostin levels. Consequently, these results may not be generalisable to Chinese people domiciled outside of New Zealand. Despite data from different participant cohorts being used in this study, serum for periostin levels were processed and stored using the same methodology [8] and using the same assay in a single clinical laboratory for all participants [16]. 


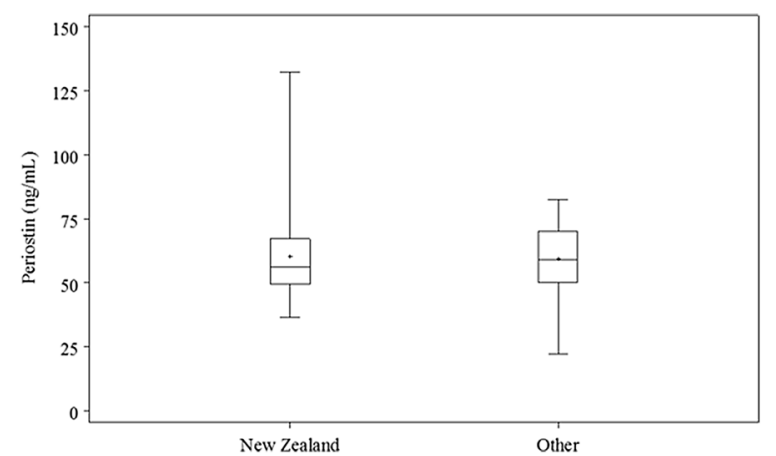

Fig. 3 Box-plot of serum periostin by country of birth for both non-asthmatic and asthmatic Chinese participants $(n=185)$. The symbol is the mean, the horizontal lines are the 25 th percentile, median and 75th percentile, and the whiskers extend from the minimum to maximum values. There was no difference in serum periostin levels between Chinese born in New Zealand versus Chinese born elsewhere

The Elecsys ${ }^{\circledR}$ Periostin immunoassay is a fully automated assay based on the sandwich principle and was developed for diagnostic purposes and use in clinical practice. Therefore, the CSLI guidelines were followed to develop an accurate, precise and reliable assay that is sufficiently sensitivity, accuracy with regard to an established target value, precision of the assay across instruments, lots and sites, and low susceptibility towards potential interferences, resulting in comparable results between separate measured cohorts over periods of time. Thus the comparisons between these groups in this study are unaffected by the intervening times between testing. Finally, the Chinese asthmatics had less severe asthma as measured by $\mathrm{FEV}_{1} \%$ predicted and asthma medication use, although this is unlikely to be of significance, as serum periostin levels are not related to asthma severity $[7,9]$.

In the Chinese non-asthma population periostin levels were sex-dependent, with females having higher periostin levels. This was an unexpected finding as it was not observed in the previous study of a predominantly Caucasian population without asthma [8], which was a larger study defining a reference range for non-asthmatic adults. It is possible that differences in key environmental or personal characteristics that influence serum periostin levels may differ between Chinese and Caucasian people, based on sex. To clarify the uncertainty, further robust data describing sex-dependent reference ranges in Chinese and other populations defined by racial background are needed.

Serum periostin levels were similar in the Chinese asthma and non-asthma groups with median values $56.8 \mathrm{ng} / \mathrm{ml}$ and $57.0 \mathrm{ng} / \mathrm{ml}$ respectively. This finding is in agreement with previous studies undertaken in predominantly Caucasian participants $[8,9]$ where serum periostin levels did not discriminate between asthmatic and non-asthmatic groups, suggesting that measurement of periostin is not a useful biomarker in establishing a diagnosis of asthma. Of note, the Chinese asthma group consisted of a range of asthmatics, some of who were not taking regular ICS. From previous studies [9], it is clear that ICS use can lower serum periostin levels by approximately $10 \%$ and whilst this is statistically significant, it is unlikely to be clinically meaningful.

However, differences between asthmatic and nonasthmatic groups have been observed in a Japanese population [17]. This could be due to differences in populations included in the studies, including polymorphisms that have been associated with periostin levels.

The observation that serum periostin was similar between the Chinese and Caucasian asthma groups is difficult to interpret given that the two groups were recruited using different methodology. The Caucasian asthmatics were recruited from the electoral roll and were not excluded if they underwent surgery or dental procedures, or sustained bone fractures prior to enrolment and had less severe asthma, as periostin was not the main focus of this study [9]. Consequently, formal statistical analysis was not performed between these asthma groups, as any meaningful conclusion would be difficult to interpret given the different approaches to recruitment between the two groups of participants. However, the serum for periostin measurement was processed in the same way, utilising the same assay [16].

Serum periostin levels were higher in Chinese, irrespective of the participant's country of birth. This finding is consistent with previous studies $[8,9]$ which have found higher serum periostin levels in those of Asian origin. Together with studies that described polymorphisms of the POSTN gene influencing serum periostin levels [17], this suggests that genetic background may play a role in determining levels of serum periostin. The clinical relevance is that race and ethnicity may be important factors to consider when interpreting serum periostin values.

The finding that different patterns for other Type 2 biomarkers between the groups were observed supports previous observations that these biomarkers may identify different aspects of Type 2 mediated inflammation [8, 18-20]. Between non-asthmatics, the periostin and serum IgE levels were higher in Chinese compared with Caucasians, whereas there was no significant difference in FeNO or blood eosinophils. In the Chinese population those with asthma had higher levels of FeNO, IgE and 
blood eosinophils, but not periostin, when compared with those without asthma.

The observation of a higher serum IgE in Chinese compared with Caucasian populations is consistent with previous findings identifying differing serum $\operatorname{IgE}$ levels between races and socio-economic groups [2123] and specifically a trend towards higher serum IgE in Chinese compared with 'White' people in England [23]. Smoking, which is associated with elevated levels of serum IgE [24] was unlikely to be a confounding factor in our study as current smokers, or former smokers with a pack year history of over 10 years, were excluded. However, participants were not assessed with regards to passive smoking, which can be a contributing factor to higher levels of serum IgE [24]. The finding that blood eosinophil levels were similar in Chinese and Caucasians without asthma is consistent with the previous observation that blood eosinophil levels are comparable between ethnicities, including 'Orientals' (defined as those who were from South East Asia, or who identified as Chinese) [25]. Our finding of similar FeNO levels between Chinese and Caucasians without asthma adds to the literature of inconsistent findings between FeNO and race [26-30]. Significantly elevated FeNO levels have been reported in Asians versus their Caucasian peers in both asthmatic [27] and non-asthmatic [29] children. The National Health and Nutrition Examination Survey (NHANES) cohort [26] found only a difference between races in children, but not in adults in a population free of respiratory diagnoses. However, Ko and colleagues report higher FeNOs in Chinese adults compared to Caucasians without chronic respiratory disease [30].

\section{Conclusions}

In conclusion, we have determined that serum periostin levels are higher in a Chinese non-asthmatic population compared with a Caucasian non-asthmatic population, suggesting that genetic background may influence serum periostin levels. If serum periostin is to be used to identify patient phenotypes in asthma or to make treatment decisions in the clinical context of asthma, these factors would need to be taken into account.

\begin{abstract}
Abbreviations
ACQ: Asthma Control Questionnaire; AQLQ-S: Asthma Quality of Life Questionnaire-Standardised activities; ATS: American Thoracic Society; COPD: chronic obstructive pulmonary disease; FeNO: fractional exhaled nitric oxide; FEV1: forced expiratory volume in one second; FVC: forced vital capacity; ICS: inhaled corticosteroid; Ig: immunoglobulin; IL: interleukin; LABA: long-acting beta agonist; LAMA: long-acting muscarinic antagonist; NZRHS: New Zealand Respiratory Health Survey; SABA: short-acting beta agonist.
\end{abstract}

Acknowledgements

We are grateful to the study participants for their involvement in this study.
The Periostin Study Group: Richard Beasley, Irene Braithwaite, Evan Tan, Rachel Varughese, Rachel-Caswell Smith, Mathew Williams, Ruth Semprini, Alex Semprini, Nick Shortt, Stefan Ebmeier, Denise Fabian, James Fingleton, Mark Holliday, Tony Mallon, Alison Pritchard, Mark Weatherall (Medical Research Institute of New Zealand); Jochen Brumm, Cecile Holweg, John Matthews, Julie Olsson, Anupama Ravi, Karl Yen (Genentech Inc).

\section{Authors' contributions}

Study conception and design: ET, RV, RCS, MW, RB, IB; Acquisition of data: ET, RV, BM, RS, RCS; Analysis: MW; Interpretation of data: All authors; Drafting of manuscript: All authors; Critical revision: RS, CH, JO, JF, MW, RB, IB. Approval for publication: All authors. All authors agree to be accountable for all aspects of the work in ensuring that questions related to the accuracy or integrity of any part of the work are appropriately investigated and resolved. All authors read and approved the final manuscript.

Funding

Genentech Inc., San Francisco, USA.

\section{Availability of data and materials}

The datasets used and/or analysed during the current study are available from the corresponding author on reasonable request.

\section{Ethics approval and consent to participate}

This trial conformed to the standards of the Declaration of Helsinki, and was approved by the New Zealand Health and Disability Ethics CommitteesNorthern B (13NTB190). Participant consent was obtained prior to the administration of any study procedures.

\section{Consent for publication \\ Not applicable}

\section{Competing interests}

Dr. Olsson and Dr. Holweg are employees of Genentech Inc., a member of the Roche Group. There are no other conflicts of interest to declare.

\section{Author details}

${ }_{1}^{1}$ Medical Research Institute of New Zealand, Private Bag 7902, Newtown, Wellington 6242 , New Zealand. ${ }^{2}$ Victoria University of Wellington, Wellington, New Zealand. ${ }^{3}$ Genentech Inc, San Francisco, California, USA. ${ }^{4}$ University of Otago, Wellington, New Zealand. ${ }^{5}$ Capital \& Coast District Health Board, Wellington, New Zealand. ${ }^{6}$ Optimal Clinical Trials, Auckland, New Zealand.

Received: 23 August 2018 Accepted: 15 December 2018

Published online: 18 December 2018

\section{References}

1. Jia G, Erickson RW, Choy DF, Mosesova S, Wu LC, Solberg OD, Shikotra A, Carter R, Audusseau S, Hamid Q, Bradding P, Fahy JV, Woodruff PG, Harris JM, Arron JR. Periostin is a systemic biomarker of eosinophilic airway inflammation in asthmatic patients. J Allergy Clin Immunol. 2012;130(647-654):e10.

2. Takayama G, Arima K, Kanaji T, Toda S, Tanaka H, Shoji S, McKenzie ANJ, Nagai H, Hotokebuchi T, Izuhara K. Periostin: a novel component of subepithelial fibrosis of bronchial asthma downstream of IL-4 and IL-13 signals. J Allergy Clin Immunol. 2006;1 18:98-104.

3. Corren J, Lemanske RF, Hanania NA, Korenblat PE, Parsey MV, Arron JR, Harris JM, Scheerens H, Wu LC, Su Z, Mosesova S, Eisner MD, Bohen SP, Matthews JG. Lebrikizumab treatment in adults with asthma. N Engl J Med. 2011;365:1088-98.

4. Brightling CE, Chanez P, Leigh R, O'Byrne PM, Korn S, She D, May RD, Streicher K, Ranade K, Piper E. Efficacy and safety of tralokinumab in patients with severe uncontrolled asthma: a randomised, double-blind, placebo-controlled, phase 2b trial. Lancet Respir Med. 2015;3:692-701.

5. Wenzel S, Swanson B, Teper A, Hamilton J, Izuhara K, Ohta S, Ono J, Zhu $H$, Zhang B, Staudinger H, Graham NMH, Pirozzi G. Dupilumab reduces 
severe exacerbations in periostin-high and periostin-low asthma patients. Eur Respir J. 2016;48:OA1798.

6. Hanania NA, Wenzel S, Rosén K, Hsieh H-J, Mosesova S, Choy DF, Lal P, Arron JR, Harris JM, Busse W. Exploring the effects of omalizumab in allergic asthma: an analysis of biomarkers in the EXTRA study. Am J Respir Crit Care Med. 2013;187:804-11.

7. Johansson MW, Evans MD, Crisafi GM, Holweg CTJ, Matthews JG, Jarjour NN. Serum periostin is associated with type 2 immunity in severe asthma. J Allergy Clin Immunol. 2016;137(1904-1907):e2.

8. Caswell-Smith R, Hosking A, Cripps T, Holweg C, Matthews J, Holliday M, Maillot C, Fingleton J, Weatherall M, Braithwaite I, Beasley R. Reference ranges for serum periostin in a population without asthma or COPD. Clin Exp Allergy. 2016:46:1303-14.

9. Fingleton J, Braithwaite I, Travers J, Bowles D, Strik R, Siebers R, Holweg C, Matthews J, Weatherall M, Beasley R. Serum periostin in obstructive airways disease. Eur Respir J. 2016:47:1383-91.

10. Sine H, Zakowski J, Horowitz GL, Altaie S, Boyd JC, Ceriotti F, Garg U, Horn P PA. EP28-A3C: defining, establishing, and verifying reference intervals in the clinical laboratory; approved guideline - third edition. Clin Lab Stand Inst. 2010.

11. Juniper EF, Bousquet J, Abetz L, Bateman ED, GOAL Committee. Identifying "well-controlled" and "not well-controlled" asthma using the Asthma Control Questionnaire. Respir Med. 2006;100:616-21.

12. Juniper EF, Guyatt GH, Epstein RS, Ferrie PJ, Jaeschke R, Hiller TK. Evaluation of impairment of health related quality of life in asthma: development of a questionnaire for use in clinical trials. Thorax. 1992:47:76-83.

13. Miller MR, Hankinson J, Brusasco V, Burgos F, Casaburi R, Coates A, et al. Standardisation of spirometry. Eur Respir J. 2005;26:319-38.

14. Quanjer PH, Stanojevic S, Cole TJ, Baur X, Hall GL, Culver BH, Enright PL, Hankinson JL, Ip MSM, Zheng J, Stocks J, ERS Global Lung Function Initiative. Multi-ethnic reference values for spirometry for the 3-95year age range: the global lung function 2012 equations. Eur Respir J. 2012;2012(40):1324-43

15. ATS/ERS recommendations for standardized procedures for the online and offline measurement of exhaled lower respiratory nitric oxide and nasal nitric oxide, 2005. Am J Respir Crit Care Med. 2005;171:912-30.

16. Palme S, Christenson RH, Jortani SA, Ostlund RE, Kolm R, Kopal G, Laubender RP. Multicenter evaluation of analytical characteristics of the Elecsys $\left({ }^{\circledR}\right)$ Periostin immunoassay. Clin Biochem. 2017;50:139-44.

17. Kanemitsu Y, Matsumoto H, Izuhara K, Tohda Y, Kita H, Horiguchi T, et al. Increased periostin associates with greater airflow limitation in patients receiving inhaled corticosteroids. J Allergy Clin Immunol. 2013;132(2):305-12.e3.

18. Arron JR, Izuhara K. Asthma biomarkers: what constitutes a "gold standard"? Thorax. 2015;70:105-7.
19. Malinovschi A, Fonseca JA, Jacinto T, Alving K, Janson C. Exhaled nitric oxide levels and blood eosinophil counts independently associate with wheeze and asthma events in National Health and Nutrition Examination Survey subjects. J Allergy Clin Immunol. 2013;132:821-7-5.

20. Matsumoto H. Serum periostin: a novel biomarker for asthma management. Allergol Int. 2014;63:153-60.

21. Litonjua AA, Celedón JC, Hausmann J, Nikolov M, Sredl D, Ryan L, Platts-Mills TAE, Weiss ST, Gold DR. Variation in total and specific lgE: effects of ethnicity and socioeconomic status. J Allergy Clin Immunol. 2005;115:751-7.

22. Gergen PJ, Arbes SJ, Calatroni A, Mitchell HE, Zeldin DC. Total lgE levels and asthma prevalence in the US population: results from the National Health and Nutrition Examination Survey 2005-2006. J Allergy Clin Immunol. 2009;124:447-53.

23. Court CS, Cook DG, Strachan DP. The descriptive epidemiology of house dust mite-specific and total immunoglobin E in England using a nationally representative sample. Clin Exp Allergy. 2002;32:1033-41.

24. Oryszczyn M-P, Annesi-Maesano I, Charpin D, Paty E, Maccario J, Kauffmann F. Relationships of active and passive smoking to total lgE in adults of the epidemiological study of the genetics and environment of asthma, bronchial hyperresponsiveness, and atopy (EGEA). Am J Respir Crit Care Med. 2000;161:1241-6.

25. Bain B, Seed M, Godsland I. Normal values for peripheral blood white cell counts in women of four different ethnic origins. J Clin Pathol. 1984:37:188-93.

26. Brody DJ, Zhang X, Kit BK, Dillon CF. Reference values and factors associated with exhaled nitric oxide: U.S. youth and adults. Respir Med. 2013;107:1682-91.

27. Linn WS, Rappaport EB, Berhane KT, Bastain TM, Avol EL, Gilliland FD. Exhaled nitric oxide in a population-based study of southern California schoolchildren. Respir Res. 2009;10:28.

28. Wong GWK, Liu EKH, Leung TF, Yung E, Ko FWS, Hui DSC, FokTF, Lai CKW. High levels and gender difference of exhaled nitric oxide in Chinese schoolchildren. Clin Exp Allergy. 2005;35:889-93.

29. Sonnappa S, Bastardo CM, Stafler P, Bush A, Aurora P, Stocks J. Ethnic differences in fraction of exhaled nitric oxide and lung function in healthy young children. Chest. 2011;140:1325-31.

30. Ko FW, Leung TF, Wong GW, Chu JH, Sy HY, Hui DS. Determinants of, and reference equation for, exhaled nitric oxide in the Chinese population. Eur Respir J. 2013;42(3):767-75.

\section{Publisher's Note}

Springer Nature remains neutral with regard to jurisdictional claims in published maps and institutional affiliations.
Ready to submit your research? Choose BMC and benefit from:

- fast, convenient online submission

- thorough peer review by experienced researchers in your field

- rapid publication on acceptance

- support for research data, including large and complex data types

- gold Open Access which fosters wider collaboration and increased citations

- maximum visibility for your research: over $100 \mathrm{M}$ website views per year

At BMC, research is always in progress.

Learn more biomedcentral.com/submissions 